\title{
Dodging the Literary Undertaker - Biographic Metafiction in Hanif Kureishi's The Last Word
}

\section{Petr Chalupský}

Hanif Kureishi's 2014 novel, The Last Word, involves most of the author's idiosyncratic themes, such as ethnicity, racism, sexual identity, examination of interpersonal relationships and the crucial role of the creative imagination in human life. Its focal concern, however, is to explore the process of writing a literary biography of a living person and the character and dynamics of the relationship between the biographer and his subject - a writer. As such, the novel can be taken as being representative of biographic metafiction, a subcategory of historiographic metafiction, which, following the postmodernist questioning of our ability to know and textually represent historical truth, presents biographic writing critically or even mockingly, rendering its enthusiastic practitioners' efforts with ironic scepticism. The aim of this article is to present The Last Word as a particular example of biographic metafiction that has all the crucial features of this genre, yet which differs from its predecessors through the complexity and thoroughness of its portrayal of the biographer-biographee relationship.

\section{Keywords}

Hanif Kureishi; The Last Word; biography; biographic metafiction; historiographic metafiction; romances of the archive

Hanif Kureishi (b.1954) is one of the most prominent members of the strong post-WWII generation of British writers who established themselves on the literary scene during the late 1970 and 1980 os. $^{1}$ The body of his work is diverse in terms of genres as it includes fiction, plays, screenplays and non-fiction. Ever since his early screenplays, My Beautiful Laundrette (1985) and Sammy and Rosie Get Laid (1987), via his most acclaimed novels, The Buddha of Suburbia (1990), Black Album (1995) and Something to Tell You (2008), and short story collections, Love in a Blue Time (1997) and Midnight All Day (1999), he has been 
exploring his most idiosyncratic themes, namely ethnicity, racism, the life of mostly Pakistani and Indian immigrants and their families in London during the last three decades of the twentieth century ${ }^{2}$, London and the relation and difference between its suburbs and inner city, relationships between parents and their children, family and familial roles and relationships, sexual and gender identity, and the importance of imagination and creativity for selfrealisation. All his stories thus revolve around various kinds of interpersonal relationships, which he always prefers to reflecting on British society as a whole (Thomas 2005, 134), with emphasis on less functional ones between spouses, partners, lovers, close friends, family members. These relationships are dissected into the most minute and intimate motives and impulses with an almost psychoanalytical sense of detail. ${ }^{3}$ The most explicit example of this tendency is his controversial novella Intimacy $(1998)^{4}$, the story of a man in mid-life crisis who is just about to leave his partner and their two small children for a younger woman, conceived as a first-person confessional narrative as if intended for the ears of a psychoanalyst. Kureishi's perspective, however, despite his frequently sceptical treatment of the functioning of interpersonal relationships, is that of humanistic optimism as for him "our differences - be they due to gender, psychological makeup, geography, religion or age - are less significant than they might seem" (Buchanan 15).

The Last Word (2014), Kureishi's most recent novel, in many respects follows this line as it features a number of more or less dysfunctional intimate relationships that suffer from the involved persons' infidelities, jealousies, quarrels, power struggles, malice and selfishness. Also, as in most of his other works, the novel contains a crucial ethnic (or postcolonial) element in one of its principal characters. However, the main axis around which the story revolves is formed neither by the conflict of different ethnicities, nor familial troubles nor the impact of the urban milieu on the characters' lives, but by the process of writing a biography and, in consequence, the peculiar evolvement of the biographer-biographee relationship. The novel thus explores yet another recurrent theme of Kureishi's fiction - the importance of storytelling, including the crucial question of "whose stories count and how they are told" (Thomas 2015, 116). With The Last Word, the author has made a contribution to so-called biographic metafiction 5 , a specific subgenre of historiographic metafiction that has been popular among British writers since the 1980 os. Being rather critical or even mocking in its tone, biographic metafiction depicts the process of biographical work, placing special emphasis on the rigours and pitfalls it 
involves and presenting the historical truth the biographer pursues as being elusive, equivocal and therefore unattainable in an unproblematic form. ${ }^{6}$ The most famous examples of this genre are Julian Barnes's Flaubert's Parrot (1984), Penelope Lively's According to Mark (1984), William Golding's The Paper Men (1984), Peter Ackroyd's Chatterton (1987), Kingsley Amis's The Biographer's Moustache (1995) and A.S. Byatt's The Biographer's Tale (2000). ${ }^{7}$ This article examines Kureishi's novel in relation to the above mentioned texts, that is as a particular example of biographic metafiction, and shows that The Last Word is the most complex and in-depth in terms of the portrayal of the intricacies and dynamics of the relationship between the biographer and his/her subject.

\section{Biography - A Life-rekindling or Pernicious Form?}

Biography is a genre with a long tradition reaching back to the Ancient Greek accounts of outstanding personages whose lives served as examples for readers to follow. The foundations of its modern form were laid by Samuel Johnson, who strictly dismissed the hagiographic tradition of medieval life writing, calling for arealistic depiction of the subject's daily life and awartsand-all approach to the person's private life as well as their public image. Although the Victorian era resumed the tradition of writing exemplary and exalting portrayals of eminent personalities "tidied up to remove any humanizing hints of indecency" (Donaldson 2), the tendency towards candid and debunking biography was not to be reversed and proceeded via the "modernist experiments with life writing as an art form" (Lee xiv) and detailed and intimate post-Freudian biographic scrutiny to the popular, contemporary "biography of revelation" (Evans 141), which recognises no taboo areas and whose primary focus has been shifted from the subject's moral qualities to their uniqueness and difference. An inevitable consequence of this development has been the massive production of low-quality biographies of all kinds of popular culture celebrities following the principle that the more risque and bizarre the disclosure they offer the more attractive they are for the book market. This does not mean that solid, quality biographies that explore "the intersection of history, society, and individual experience", render "character in the round", and tell "a generously contexted story" (Kaplan qtd. in Donaldson 5) are no longer produced, they are only rather scarce and more difficult to find in the heap of sensation-driven, tabloid gossip-filled bestsellers. 
This may partially help explain why biography, in spite of its steadily rising popularity, is still treated with caution in academic circles. However, recent critique does not concern only its popular forms since even if the biography's "artistic status is granted, it is accused of being a particularly pernicious form" (Tridgell 14). Under the pressure of postmodernist and poststructuralist revisioning and challenging of the most fundamental presumptions about an individual's self, its nature, formation, and elusive and ambiguous existence in an ever changing world of minimal certainties, the biography has assumed the daunting task of satisfying "the deep desire of late twentieth-century society for order and stability" (Evans 134) by conveying the impression that life may be presented as orderly and consequential. Such accounts, therefore, offer solace and comfort to people who more than ever before experience their lives as fragmentary, arbitrary and unpredictable, by "embracing documentation and emphatically chronological narrative" in order to "maintain, through the written word, a sense of [self] as a coherent person" (Evans 26). What contradicts this project, apart from the obviously inevitable lack of evidence which could reveal another person's life in its wholeness and the necessity of selecting which of the available pieces of evidence to include, is the role of self-construction, that is that every person, though to a varying degree, has the tendency to create him/herself not only with respect to the prevailing social stereotypes, but also in relation to his/her imagination, desires and self-projections, which only further obscures the image of what this person is really like for an outside observer.

There are other factors undermining the notion that biography is an unequivocal and truthful account of someone's life. One of them is the discrepancy between the biographee's public and private selves and the fact that the better availability of the first may lure the biographer to mistake it for the latter. A significant role in the process of life writing is of course played by the personality and character of the biographer, whose mind can never be devoid of personal assumptions about the subject and expectations of presenting the subject's self to the reading public. The biographer's personality is also exposed to the socio-cultural environment in which he/she lives and works, and his/her approach to processing materials and shaping them into a narrative is affected by the internalised norms, conventions and values espoused and promoted by this society. And there is one more crucial subjective aspect of biography, which is not so decisive in fiction and historiography - the biographer's attitude to the subject: it can never be wholly neutral and is also 
very likely to change, both for the better and the worse, during the process of collecting and researching the materials. The final image of the biographee is also conditioned by the formal limitations of the narrative: not only does the scope of a volume not allow all aspects of the subject's life to be included, the prevailingly chronological narrative structure of most biographical works also reduces the complexity of the individual's life by dismissing those aspects of experience that the author deems marginal.

Therefore, though traditionally taken as a branch of non-fiction, biography in some respects defies this classification as, apart from methodical research, it also involves the author's subjective treatment of the findings, especially in selecting facts, surmising links between them and using narrative techniques so as to shape the diverse collected materials into a coherent and consistent text. Ray Monk, for instance, argues that in its essence biography is a profoundly non-theoretical enterprise which is closer to philosophical inquiry than to scholarly work as they both share the same objective of "understanding that consists in seeing connections" (528). However, in order to establish these connections and present them credibly to the reader the biographer cannot avoid assuming a certain point of view which means that, to some extent, he/ she becomes a creative writer who cannot merely list the verified data but must conceive a narrative around them in order to "materialise" and extrapolate the subject's personality and life experience. Indeed, Michael Holroyd, a prominent British biographer, sees this approach as perfectly justifiable and likes to use the term "nonfiction stories" for biographic writing (Cohen).

Despite the ambiguity concerning its literary status, the necessity of assuming a subjective point of view, and the sceptical voices insisting that it can offer "only a plausible, inevitably idiosyncratic surmise and reconstruction, severely limited by historical materials that are loaded with duplicities and evasions" (Kaplan qtd. in Donaldson 118), it would be wrongful and unsubstantiated to condemn biography as mere fabrication, incapable of producing any added value to the bald facts. It is true that it is impossible to get wholly inside someone's mind and heart and thus narratively reconstruct this person in his/her complexity, but if the biographer is genuinely interested in the subject, that is "diligent and devoted, persistent and perceptive enough, [he/she] may come close" (Donaldson 120). A well-written biography can then function as a valuable guide on the never-ending path to understanding our human nature, with its universalities as well as individual differences. By converting a person into a related text, Holroyd notes, life writing creates "a reading principle, 
with possibilities of illumination and enrichment", the aim of which is to "rekindle life" $(26,19)$. Each such biography represents an arduous attempt to defy the ultimate relativism that may lead to a dangerous abandonment of the ambition to obtain any truthful version of human experience.

\section{Biographic Metafiction - A Mock-Romance of the Archive}

Thematically, biographic metafiction is related to another genre of fiction popular in British literature of the last few decades - the so-called "romance of the archive" 8 , in which the main protagonists assume the role of researchers, either professional or amateur, in order to discover some truth about the past. What connects the two genres is the protagonist's quest for historical evidence, in the course of which a significant part of their research is carried out in places where textual historical documents are kept, such as archives, libraries and private collections. What crucially distinguishes them, however, is not so much the purpose of their research, i.e. that in romances of the archive the characters only very rarely publish their findings, but their basic premise and the consequent spirit of their narratives: in romances of the archive the past is "approachable, [...] mapped onto recognizable places" (Keen 2001, 130), and they insist that historical truth can be found with the help of textual documents whose ability to recover and represent this truth is not questioned but affirmed, as a result of which confusion is made sense of, mystery resolved, a satisfying closure permitted, and historical injustices redressed (Keen 2006, 176). The protagonists are thus, in the spirit of the ancient heroic tradition, rewarded for their efforts and hardships not only in the form of gaining what they were searching for, but also in the form of achieving an improved character and the requited affection of the beloved person. Biographic metafiction, on the contrary, is far more sceptical concerning the representational value of textual documents, which are always shown, to some extent, as being problematic: incomplete, biased, misleading, and therefore unreliable. As a branch of historical metafiction, biographic metafiction stems from postmodernist challenging and revision of the notion of historical truth and our ability to unproblematically know it and represent it in language. It considers history to be discursively produced and structured, and raises the question of whose history survives in textual evidence (Hutcheon 119-120), and as such it effectively mocks what romances of the archive take 
for granted. As a result, it offers no such consolatory endings, the protagonists often abandon their biographic research and do not complete their quest, and even if they do publish their biography it differs from the one they originally intended to write.

Like historiographic metafiction, biographic metafiction highlights that the past can only be accessed in a mediated form, mostly through textual and other discursive productions, which never provides a transparent and reliable account of historical events or individuals' lives. Consequently, it also blurs the borderline in life writing between fact and fiction, the real and the made up and problematises the notions of objectivity, truth and the issue of representation itself. Unlike traditional biographical fiction, it does not recount someone's life story but explores and lays bare the very processes involved in the biographer's struggle to amass materials from which he/she could compile the subject's identity, namely those of selection and ordering, emphasising that "any biographical representation is an intellectual construct" and "what is commonly regarded as a biographical fact inevitably depends on the selective bias of the individual biographer" (Nünning 205). Therefore, biographic metafiction revolves around the unbridgeable gap between lived experience and its comprehensive textual depiction, showing how the immense, often uncontrollable or even chaotic, dynamics of people's lives always elude being pinned down by the limited possibilities of the written medium.

Generally, there are two kinds of biography writing that this genre depicts: either the biographee is a living person, the biographer's contemporary, or is already deceased. In the latter instance, biographic metafiction, such as Flaubert's Parrot, According to Mark, Chatterton and The Biographer's Tale, centres on the obstacles such an enterprise entails, particularly the lack or absence of evidence and leads, their contradictoriness and unreliability, and the untrustworthiness of the surviving witnesses' testimony. In the case of living biographees, such as in The Paper Men, The Biographer's Moustache and Michael Palin's The Truth (2012), the above mentioned rigours are supplemented with the often obtrusive, irritating, disruptive or even menacing presence of the biographee, and it does not matter much whether he/she has given consent to the biography, the only difference being that if they have given such consent they turn into a nuisance a little later when the biographer proceeds with the research. The process of the growing antagonism between the biographer and subject can be gradual and subtle yet intense, which is precisely the case of Kureishi's The Last Word. 


\section{The Extreme Biography/ee - The Last Word}

Harry Johnson, the novel's main protagonist, is a young writer and a promising biographer who, based on the moderate success of his biography of Jawaharlal Nehru, is commissioned to produce a biography of Mamoon Azam, a renowned Indian-born novelist, essayist and playwright who made his career in England in the 1970s, 8os and early 9os. He feels exceptionally excited at and honoured by this opportunity as he has admired and venerated Mamoon's writings and ideas ever since he was a book-loving teenager. He sees himself as having been specially chosen to present to the general public a comprehensive and veracious portrayal of this literary guru and eminent and outspoken voice of the postcolonial domain, "to tell the whole story of this important man, this significant artist" (The Last Word9 1 ), and "to give a true account of his fascinating life" $(L W 17)$. However, Harry is soon to learn that his optimism and idealism will be difficult to sustain when faced with the naked reality of his hero's present-day life situation, which is very much unlike his professional image as a perceptive and insightful thinker who is above the mundane concerns that preoccupy his less exceptional fellow citizens.

Mamoon, who is in his early seventies, is in fact almost a caricature of someone who has put himself out to pasture. Not only he has not written anything for years, but he has also abandoned all the values and principles that made him famous and respected in the intellectual world, particularly critical public discourse, and he is entirely oblivious not only to world affairs, but to everything that transcends the narrow horizon of his day-to-day "base" existence: having retreated to his house in the country he shows no interest in anything but food, drink, watching cricket and football on television and craving gossip and tabloid news. The biographical project is thus orchestrated by his second wife, Liana, and the publisher, Rob Deveraux, whose motivation and aims are far less high-minded and artistic than Harry's. This coalition, though from both sides motivated by the idea of financial profit, is, however, a paradoxical one given their contradictory hopes regarding the nature of the final product.

The sales of Mamoon's books have been steadily falling and although the income may be generous enough for his modest needs it proves wholly insufficient to cover his wife's spending plans. Liana, some twenty years younger than her husband, attractive and still very active, married Mamoon out of a combination of love and adulation, becoming voluntarily a kind of "Tolstoy's wife" ( $L W 33$ ), ready to provide her husband with as much care 
and comfort as he needed so he could fully concentrate on his writing. All the while, she has been cherishing the hope of buying a house in London and living the socially vibrant and extravagant life of a literary celebrity's wife. It is only when she realises that her husband does not share her ambition of moving to the capital and does not even plan to write at all, that she decides, in despair, to revitalise his career and get his books back in the public eye by having his biography, or, rather hagiography, written. The publisher then sees the potential for a best-seller, yet only if it is a controversial, "extreme biography" ( $L W 9$ ), which would expose and examine his character flaws and the risqué aspects of his private and intimate life rather than his literary achievements. This is where Rob approaches Harry, in part because he already has experience with writing a biography on an Indian subject, and in part because he is still largely unknown and therefore inexpensive to hire.

Harry thus finds his idea for Mamoon's life story ground between the millstones of Liana's and Rob's conflicting requirements. Moreover, the undermining of his idealism and artistic independence is not the only cause for concern, as he also recognises the pragmatic side of the project: he is planning a future with his fiancée, Alice, who has recently moved into his flat and he realises that the success of his book could help them achieve the financial prosperity he dreams of. Yet he soon finds out that though the wife and the publisher can be a nuisance at times, the true trouble in his enterprise will be the biographee himself. Although Rob warns Harry that writing about somebody who is alive has its pros and cons since the subject may cooperate with the biographer, as well as inhibit his/her work, and that, as far as he knows Mamoon's character, the "old man will exasperate [him] with his stubbornness and taunting" ( $L W 8)$, it is only when he meets his subject in person that he comes to understand how much easier it was to write about somebody who can no longer fight back, and how euphemistic Rob's words about inhibition were as "sabotage" would have been more apt description.

Although Mamoon is aware of the rational reasons behind the project and officially gives consent to it, in reality he refuses to accept and go along with the idea for several good reasons. First, he is used to enjoying the quiet and uneventful comfort and privacy of his home and does not long for publicity or any other form of intrusion to potentially disturb this status quo. Second, he feels useless and worn-out because of he is to becoming a biographic subject, which he believes suggests that his working, and perhaps not only his working, life is over and that all he is good for in his remaining time is to produce his memoirs. Third, as he still considers himself a venerable writer, 
he does not appreciate that his life will be written up by a nameless young hack to whom he feels superior in all respects. And fourth, he has become weary of his discontented and hard-to-please wife's caprices and aspirations, of her material, emotional and physical demands, of her ceaseless attempts to force him into something that is not to his taste. For these reasons, augmented by Mamoon's general antipathy towards literary biography - he calls the biographer "the undertaker of the literature world" ( $L W 80$ ), the task that awaits Harry appears to be far from easy.

Given the above outlined state of affairs, The Last Word has all the parameters that distinguish biographic metafiction. In fact, the beginning of the story resembles that of Kingsley Amis's The Biographer's Moustache, in which a young, aspiring writer, Gordon Scott-Thompson, is also commissioned to write the biography of an elderly, once famous novelist, Jimmie Fane, whose work he considers to be unjustly neglected and he therefore hopes his book would bring them back to the reading public's attention. However, Fane as a person turns out to be an arrogant, condescending snob who delights in patronising and humiliating the younger man for his inexperience and, most of all, for his lower social status, and who, moreover, attempts to inflict his censorship on those of Gordon's materials which may shatter his meticulously fostered image as a respectable, upper-class intellectual. In both novels, the biographers start their research with idealistic enthusiasm and respectful admiration of their subjects' writing, opposing the publishers' insistence on primarily exposing "the juicy bits" (Amis 17), only to discover that the subjects in the flesh are quite unlike the "theoretical" persons extrapolated from their words on paper. Also, the subjects inhibit the biographers' work by trying to exercise control over the content, as well as by their reluctance to speak about certain aspects of their personal life. As a result, the biographers end up with little more than they had initially, that is the biographees' works and some generally known facts, mostly in the form of the not wholly reliable testimonies of former wives and mistresses, which the subjects find uncomfortable and compromising and therefore do not approve of having in their biographies. Consequently, both novels depict the process of the biographers' gradual yet profound awakening to reality, involving all its stages from disappointment, disillusionment and anger to a bitter revisioning of the original idea behind the project and even thoughts of retaliation.

However, there are some substantial differences between the two stories. First, the role of the biographer's and biographee's social background is not prominent in The Last Word, and although Mamoon does feel some kind of 
superiority over Harry, it is not based on class. In fact, the roles are to some extent reversed here compared to The Biographer's Moustache as due to his ethnic origin Mamoon has been an outsider ever since he moved from India to Britain, a liminal character too white for the Indians yet too Indian for the British, a classless person who, despite his talent and potential, has had to strive hard to gain respectability and prestige as an immigrant writer. The middle-class Harry, on the other hand, as Liana points out, has had a far easier life of limitless opportunities and minimum barriers, flying through it "on a magic carpet of privilege" ( $L W 69)$. Therefore, if Mamoon looks down on Harry it is not so much from a position of social standing and affluence, but from a feeling of artistic and intellectual superiority, bolstered by his profound dislike and distrust of literary biographers.

The second major difference is the relationship between the biographer and the subject's wife. In both books these women are older than the biographers but still very attractive, active and confident. Yet, while Gordon falls for Fane's wife and develops a relationship with her, Harry shows no such affection towards Liana and instead has an affair with Julia, a young woman employed as a housemaid on the Azams' estate. What the two young writers have in common, then, is the fact that they are being unfaithful to their girlfriends while working on their projects, but only Gordon technically becomes a "rival in love" to his biographee. However, in reality this difference is not as unequivocal as it seems: the self-assured, pompous and cynical Fane never really comes to admit that his wife could leave him for what he sees as a destitute scribbler and so does not see Gordon as a competitor in this regard. Mamoon, on the other hand, though Harry is no threat to his marriage, is jealous of Harry's youthful and carefree infidelities and love affairs. He envies him what he lacks most, and what he was used to as an acclaimed writer - the devoted yet undemanding love, care and attention of a woman, preferably a young one, as for him a woman is "always other, and a provocation" ( $L W$ 171 ), "the body of the young woman is the world's most significant object" ( $L W$ $174)$, adultery "the only fun left" ( $L W 100)$, while marriage is merely a kind of pragmatic "defence, a levee against the turbulence of desire" ( $L W 100)$. And so it is the relationship between Mamoon and Harry that could be described in terms of rivalry in love, though initially not over a specific person but over amorous opportunities in general.

The two novels also differ in the final form of the books the biographers produce. As Gordon discovers his once favourite writer's true character and suffers Fane's vanities and conceited verbal assaults, he not only loses all his 
illusions and good opinions about his subject, but decides to take revenge in the form of a revelatory, warts-and-all biography, the one his publisher wanted him to write. The fact that, after all, the complacent Fane finds the book helpful in reviving his popularity, claiming that negative publicity is better than no publicity at all since " $\mathrm{t}$ ] hese days the public like to think of an artist as a, as a shit, known to behave in ways that they themselves would shrink from" (Amis 250), is one of the story's central ironies. Although Harry also goes through a similar process of disillusionment concerning his biographee's personality and exposure to his countless whimsies and fits of peevishness, and although he at times also thinks of making his book more "juicy" by using Mamoon's former mistress Marion's, spiteful testimonies about the old man's callous and inconsiderate treatment of women, he eventually keeps his composure, resists the temptation and writes the kind of biography he has intended to write from the start, an "intimate, psychological portrait" ( $L W 234)$ yet without defaming the esteemed writer and his literary legacy. Indeed, in the end, Harry's attitude towards his biographee is unlike Gordon's aversion to Fane. Although his uncritical admiration has waned he is far from disliking the old man, and even misses "their combative conversations" that "made him think so hard" ( $L W 335)$. And so it is Mamoon who wreaks vengeance on Harry by writing his final, semi-autobiographic novel, in which he turns his biographer into a laughable and morally feeble character.

The most crucial difference, which makes The Last Word so much more in-depth, or even suffocating, in its depiction of the biographer-biographee relationship, is the permanent physical proximity of the two men caused by Liana's decision to invite Harry to stay in their house in order to be close to the object of his research. Harry soon learns that his plan of conducting long interviews with Mamoon was hopelessly naïve as the fact that the old man is doomed to encounter his biographer on a daily basis makes him even more sulky, defiant and determined to sabotage all Harry's attempts at instigating some serious conversation. Also, as the time passes and Harry is growing impatient and persistent, Mamoon becomes all the more obstinate in his reluctance to talk to him about himself, as well as all the more resourceful in his strategies to fend off his adversary and discourage him from the project once and for all. Some of these strategies are rather moderate, such as lying, deceiving and concealing information, some are more unscrupulous, such as verbal bullying and intimidating, and some are downright farcical, such as howling at night, trying to defeat the young man at tennis and even beating him up with a stick. Moreover, as in a similar spirit Mamoon is also tormenting 
his wife, whom he rightfully blames for his current misery, the atmosphere in the household becomes unbearable for Harry to live and work in.

The deadlock fortunately breaks for Harry, who has already given up his hopes, after his fiancée arrives at the Azams' for a weekend stay. Mamoon is suddenly as if sprinkled with the water of life, he spends most of his time alone with Alice and quickly develops affection for the young woman, who is not only pretty and charming, but also willing to listen to him without asking questions or placing demands, and who, on top of all this, manages to alleviate his agonising backache through massage. Suddenly, Mamoon is transformed; he has no secrets from Alice and confides to her everything Harry has ever unsuccessfully tried to elicit from him. Yet Mamoon's new attitude should be no surprise for Harry as it is totally in accord with his earlier remark that he has "the feeling that a young woman's presence would make [him] more voluble" ( $L W 104)$. It is ironic that it is thanks to Alice, to whom he has been repeatedly unfaithful, and who in turn betrays him emotionally and spiritually with Mamoon, and with whom he finally breaks up in spite of the fact that she is pregnant with his child, that Harry can complete the book he has been working on for so long. It is only at this moment that Harry realises how much his personal life resembles that of the younger Mamoon, recalling the old man's observation that "everything we really desire is either forbidden, immoral or unhealthy", and his advice not to "forsake your desire, even if you're punished. Take the punishment gracefully, as a tribute, and never complain" ( $L W 275)$, and how hypocritical it would be to pretend he is not aware of it. This realisation is also one of the chief reasons why Harry rejects the idea of including discrediting materials on the writer in his book.

\section{The Subject Writes Back - Conclusion}

In biographic metafiction the argumentative and adversary nature of the relationship between biographer and living subject may easily turn it into a duel over who will have the decisive say over the print version of the biography as the subjects tend to strive "to see to it that they have the last word" (Lively 106). Very often the biographees try to exercise some control over the materials their biographers use while their research is in progress, and in some cases, sometimes despite continuous censorship, they do not approve of what the biographers see as the final products of their enterprise and make 
strong efforts to intervene in order to prevent what they perceive as untruthful or even denigrating from being published. Needless to say, if the biographer does not consider these objections relevant and legitimate their possibilities to do so are rather limited since the biography is then published as unauthorised and the biographee can only sue its author for libel afterwards. However, no such legal action has yet been rendered by a biographic metafiction novel, and therefore it remains a challenge for the genre to tackle. In the novels discussed here the "injured" person finally, for some reason, comes to terms with the situation, be it that he finds in it some benefit or profit, as in The Biographer's Moustache, or because he is already too old and ill, as in The Last Word, in spite of the fact that in the latter the two men have been waging "a war of stories" in which writing becomes "an instrument of revenge against injustice and a form of self-justification" (Thomas 2015, 121, 122).

Yet the subjects of literary biography do have another way to settle their accounts with a "rogue" biographer which other biography subjects can hardly take advantage of - they can write back, that is they can turn the biographer into a disagreeable character in their own book. Mamoon toyed with this idea from the moment Harry moved into his house and by no means keeps it to himself: "I'd like you more as a fictional character, and you should be flattered to appear in one of my works, even without your trousers" ( $L W 101)$, he notes to Harry who just takes it as one of the old man's intimidating scoldings. Yet, as the biography starts to take shape despite Mamoon's inactivity and obstructions, he feels more and more like a helpless puppet forced to live "an imaginary life" ( $L W 241)$ in someone else's story and decides to fight back - by writing a novel about what he has lived through from his own perspective, thus making himself a likeable character readers are meant to sympathise with as against the unprincipled intruder who is trying to make a career out of him. Mamoon's book is based on his own short affair with Alice and describes the semi-humorous platonic love story of an old man and a younger woman whose relationship is full of respect, tenderness and understanding, while her boyfriend, a pitiably comic figure nicknamed "Fizzy Pants", irresponsibly pursues his shallow love affairs.

Making Harry into a ludicrous fictional character is only part of the retaliation. Mamoon also allows the character based on Alice all the privileges Harry once hoped he would be granted as his official biographer: he tells her about the most private and intimate aspects of his life, he discusses with her the ideas of his best works and lets her help him apologise to and reconcile with the people he has hurt. Although the publication of Mamoon's book 
takes Harry by surprise, the question of who has the final word remains unresolved: by this time Mamoon is too fragile and paralysed by several strokes to enjoy his retribution, and Harry thus has time to add to the end of his book, symptomatically entitled Among Strangers, "a few paragraphs about the dying writer" ( $L W 339-340)$. Moreover, there are others vying to have the last word, namely Marion, who has been working on her own version of her life with Mamoon, and Liana, who is going to write an autobiographic selfhelp book about how to capture the heart of a successful man, marry him, and take charge of his life and career.

By employing his favourite strategy of self-subversion ${ }^{10}$ and the dubious reliability of the narrators, Kureishi's novel remains equivocal in terms of the interpretation of the two central protagonists' positions within its plotline. Neither Mamoon nor Harry can aspire to the role of an admirable hero of the story as both turn out rather morally ambiguous characters. Moreover, in terms of the power over the stories they wish to tell they are in fact overcome by the female characters who seemed to have been reserved the passive roles of wives, mistresses, caregivers or muses. Similarly, professional writing receives a paradoxical treatment which, on the one hand, presents the writer as a bearer of original and forward-looking ideas and, on the other one, as a hypocrite, opportunist and parasite, and which extols the act of writing as the essence of humanity and civilisation while, simultaneously, discredits it by pointing out to its corrupting and exploiting potential.

It is especially the thorough and intimate portrayal of the biographerbiographee relationship and the inconclusiveness of the novel's ending that make The Last Word an outstanding achievement within the realm of biographic metafiction. Although it bears all the typical traits of the genre it differs from its predecessors in its complexity of character and plot construction. Kureishi's narration is at times sardonic, farcical and mischievous, yet always playful and gripping, his characters act at times maliciously and egotistically, yet are always life-like and, in their way, compelling. The idea of the biographee's writing back at the biographer and its possible consequences adds a new dimension to the novel's backbone storyline and allows the author to explore both the intricacies of human nature and the problematic issues of literary biography from a slightly different perspective. By being simultaneously thought-provoking and entertaining, The Last Word aptly demonstrates that biographic metafiction still has the potential to address concerns beyond the scope of its primary focus, and that despite its relatively limited thematic and narrative possibilities the genre has definitely not yet said its last word. 


\section{PETR CHALUPSKÝ}

\section{Notes}

1. From its other members we can mention, for example, Julian Barnes, Jim Crace, Salman Rushdie, Ian McEwan, Martin Amis, Graham Swift and Kazuo Ishiguro.

2. Though born in London, Kureishi himself is of half-Pakistani origin from his father's side.

3. Jamal Khan, a middle-aged man of Pakistani-English heritage and the main protagonist of the novel Something to Tell You is even a psychiatrist by profession.

4. For a more detailed analysis of this novella including the reasons for its controversial status see Chalupskýs article "Prick lit or naked hope? Self-exposure in Hanif Kureishi's Intimacy".

5. The term "biographic metafiction", however, is not the only one used for this kind of fiction as Matt Seidel, for instance, speaks of the "literary biography novel" and Ansgar Nünning of the "fictional metabiography", but I consider it the most apt among the proposed ones.

6. In The Last Word Kureishi thus resumes the moderate and affirmative satirical tone of his earlier stories from the collections Love in a Blue Time (1997) and Midnight All Day (1999) which, also due to "moments of low-key revelation which galvanise their protagonists towards self-renewal", Moore-Gilbert (159) compares to that of Chekhov's short stories.

7. An analysis of these novels as examples of biographic metafiction can be found in Chalupskýs article "Biography as the Less Truthful Form - Contemporary British Biographic Metafiction".

8. The term is in detail introduced, delineated and exemplified in the first two chapters of Suzanne Keen's monograph Romances of the Archive in Contemporary British Fiction.

9. In subsequent references abbreviated as $L W$.

10. Susie Thomas (2015) demonstrates how this tendency can be observed in Kureishi's fiction also on the stylistic level in the form of self-subverting sentences, that is sentences whose end somehow disrupts or contradicts their beginning.

\section{Works Cited}

Amis, Kingsley. The Biographer's Moustache. London: Flamingo, 1996. Print. Buchanan, Bradley. Hanif Kureishi. London: Palgrave Macmillan, 2007. Print.

Chalupský, Petr. "Prick lit or naked hope? Self-exposure in Hanif Kureishi's Intimacy." Brno Studies in English, 37.2, 2011: 61-77. Print.

---. "Biography as the Less Truthful Form - Contemporary British Biographic Metafiction." International fournal of Linguistics, Literature and Culture, 4.1, 2017: 141-163. Print.

Cohen, Lisa. An interview with Michael Holroyd. The Paris Review. 2013. Web. 20 January 2017.

Donaldson, Scott. The Impossible Craft: Literary Biography. Pennsylvania: The Pennsylvania University Press, 2015. Print. 
Evans, Mary. Missing Persons: The impossibility of auto/biography. London and New York: Routledge, 1999. Print.

Holroyd, Michael. Works on Paper: The Craft of Biography and Autobiography. Berkeley, Counterpoint, 2013. Print.

Hutcheon, Linda. A Poetics of Postmodernism. London: Routledge, 1992. Print.

Kaplan, Justin. “What Biographies Can't Do.” Boston Review, June 1986: 9-10. Print.

Keen, Suzanne. Romances of the Archive in Contemporary British Fiction. Toronto: Toronto University Press, 2001. Print.

---. "The Historical Turn in British Fiction." A Concise Companion to Contemporary British Fiction. Ed. James F. English. Oxford: Blackwell Publishing, 2006. 167-187. Print.

Kureishi, Hanif. The Last Word. London: Faber and Faber, 2015. Print.

Lee, Hermione. Biography: A Very Short Introduction. Oxford: Oxford University Press, 2009. Print.

Lively, Penelope. According to Mark. London: Penguin, 2011. Print.

Monk, Ray. "Life without Theory: Biography as an Exemplar of Philosophical Understanding." Poetics Today, 28.3, 2007: 527-570. Print.

Moore-Gilbert, Bart. Hanif Kureishi. Manchester and New York: Manchester University Press, 2001. Print.

Nünning, Ansgar. "Fictional Metabiographies and Metaautobiographies: Towards a Definition, Typology and Analysis of Self-Reflexive Hybrid Metagenres." Self-Reflexivity in Literature. Ed. Werner Huber, Martin Middeke and Hubert Zapf. Würzburg: Königshausen Neumann, 2005. 195-210. Print.

Seidel, Matt. "Biographers Cannot Be Choosers: On the Biographical Drive." themillions.com. 2014. Web. 20 January 2017.

Thomas, Susie (ed.). Hanif Kureishi: A reader's guide to essential criticism. London: Palgrave Macmillan, 2005. Print.

---. "The Last Word on Hanif Kureishi." Hanif Kureishi. Ed. Susan Alice Fischer. London and New York: Bloomsbury Academic, 2015. 115-130. Print.

Tridgell, Susan. Understanding Our Selves: The Dangerous Art of Biography. Bern:

Peter Lang, 2004. Print.

PETR CHALUPSKÝ is Associate Professor at the Department of English Language and Literature, Faculty of Education, Charles University, where he 


\section{PETR CHALUPSKÝ}

teaches courses in English Literature, Literary Studies and Literary Theory. His research and publication activities focus on contemporary British fiction. He is the author of the monographs The Postmodern City of Dreadful Night: The Image of the City in the Works of Martin Amis and Ian McEwan (2009) and A Horror and a Beauty: The World of Peter Ackroyd's London Novels (2016).

petr.chalupsky@pedf.cuni.cz 